\title{
Infectivity of Norovirus GI and GII from Bottled Mineral Water during a Waterborne Outbreak, Spain
}

\author{
Susana Guix, Cristina Fuentes, Rosa M. Pintó, Albert Blanco, Aurora Sabrià, \\ Eduard Anfruns-Estrada, Virginia Rodríguez Garrido, Manuel Alonso, \\ Rosa Bartolomé, Thais Cornejo, Tomàs Pumarola, Albert Bosch
}

During a waterborne outbreak of norovirus in Spain, we estimated $50 \%$ illness doses for a group of exposed (secretor) persons to be 556 (95\% Cl 319-957) genome copies/day for norovirus $\mathrm{GI}$ and 2,934 (95\% Cl 1,683-5,044) genome copies/day for norovirus GII. Use of a propidium monoazide viability assay reduced these values.

Tuman noroviruses are a major agent of acute 1 gastroenteritis, are distributed worldwide, and affect all age groups (1). One of the largest outbreaks of infection with norovirus, caused by consumption of contaminated bottled spring water, occurred in Spain during 2016 and affected $>4,100$ persons (2). Multiple genotypes (GI.2, GII.2, GII.4, and GII.17) were identified among patients, and high levels of norovirus genomes were quantified in contaminated water coolers.

Differences in susceptibility to infections with different genotypes have been described and depend on expression of histoblood group antigens (3), for which expression is determined primarily by the FUT2 gene. Although secretor-negative persons are resistant to several norovirus genotypes (3), symptomatic infections in nonsecretors have been documented for GI.3, GII.1, GII.2, GII.3, GII.6, GII.7, GII.4, and GII.17 (3). These differences, which are based on host genetic susceptibility, partially hamper development of dose-response models.

Noroviruses are highly infectious, although infectivity might vary between genotypes, and data on

Author affiliations: University of Barcelona, Barcelona, Spain

(S. Guix, C. Fuentes, R.M. Pintó, A. Blanco, A. Sabrià,

E. Anfruns-Estrada, A. Bosch); Vall d'Hebron University Hospital, Barcelona (V. Rodríguez Garrido, M. Alonso, R. Bartolomé,

T. Cornejo, T. Pumarola)

DOI: https://doi.org/10.3201/eid2601.190778 their infectivity are still scarce. Reported doses causing infection in $50 \%$ of exposed persons $\left(\mathrm{ID}_{50}\right)$, determined from volunteer secretor adults challenged with a GI.1 from a stool specimen, range from 18 (95\% CI 1-4,350) $(4,5)$ to 2,800 (95\% CI, 290-25,000) genome equivalents (6).

Using human intestinal organoids, Costantini et al. estimated the $\mathrm{ID}_{50}$ for stool specimens containing GII as 440-4,000 genome copies/mL (7). Because genome to infectious virus ratios might be sample specific, especially in environmental samples, determining norovirus infectivity from common-source outbreaks and naturally contaminated samples is essential. Data reported for oyster-related norovirus outbreaks by Thebault et al. inferred higher infectivity estimates: secretors had an $\mathrm{ID}_{50}$ of $7.1\left(95 \% \mathrm{CI} 0.73\right.$ to $\left.>10^{6}\right)$ virus genomes/oyster consumed and a dose causing illness in $50 \%$ of exposed persons of 32 (95\% CI 1.32 to $\left.>10^{6}\right)$ virus genomes/oyster consumed for norovirus GI and an $\mathrm{ID}_{50}$ of $1.6\left(95 \% \mathrm{CI} 0.74\right.$ to $\left.>10^{6}\right)$ virus genomes/ oyster consumed and a dose causing illness in $50 \%$ of exposed persons of $4.86\left(1.24\right.$ to $\left.>10^{6}\right)$ virus genomes/ oyster consumed for norovirus GII (8).

In this study, we estimated the $50 \%$ illness dose in conditions of natural exposure to contaminated water. These persons were selected from a group of exposed persons during a large waterborne outbreak in Spain in 2016 (2).

\section{The Study}

This study was conducted in accordance with the Declaration of Helsinki, and approved by the Ethics Committee of the Hospital Universitari Vall d'Hebron (PR[AG]211/2016). Informed written consent was obtained from all persons.

We provided a questionnaire on water consumption, occurrence, type and duration of gastroenteritis 
symptoms, and blood type $(\mathrm{ABO})$ to 26 persons who had been exposed to drinking water from a water cooler in Spain during 2016. Acute gastroenteritis was defined as vomiting or diarrhea ( $\geq 3$ loose stools within 24 hours) and $\geq 2$ of the following: nausea, abdominal pain, or fever (temperature $\geq 37.8^{\circ} \mathrm{C}$ ). We collected saliva samples to determine secretor status by genotyping the FUT2 gene (9). We collected stool specimens during the symptomatic phase from 13 of 15 symptomatic patients and screened for norovirus by real-time quantitative PCR as described (10). We also performed genotype analysis for polymerase and capsid genes (11) and used probit analysis to determine the $50 \%$ illness dose.

A total of $69 \%$ of persons were secretors and $31 \%$ were nonsecretors (Table 1 ). The overall attack rate for symptomatic infection was 58\%: $67 \%$ for secretors and $38 \%$ for nonsecretors. Percentages of secretors were $80 \%$ for symptomatic persons and $55 \%$ for asymptomatic persons. According to water intake, $62 \%$ reported consuming $200-600 \mathrm{~mL} /$ day, $23 \%$ reported consuming $601-1,000 \mathrm{~mL} /$ day, and $15 \%$ reported consuming $>1,000 \mathrm{~mL} /$ day. We found no major differences in water consumption between secretors and nonsecretors. An increase in the proportion of symptomatic persons and the amount of water consumed daily was observed only for secretors (Figure). Gastroenteritis developed in 3 of 8 nonsecretors even though they had not ingested the largest amount of water.

Of 8 exposed nonsecretor persons, 3 (38\%) showed development of acute gastroenteritis and only GI viruses were detected in their stool. Although we could not completely rule out that GII viruses might have also infected these persons but were not detected, it is plausible that gastroenteritis in these persons was related to the GI infection. Although binding of GI.2 to nonsecretor histoblood group antigens has been demonstrated in vitro (12-14), we report clinical infections in nonsecretors. The observed attack rate for a symptomatic GI infection was similar between secretors (50\%) and nonsecretors (38\%).

We used data for quantification of norovirus in the contaminated water cooler to which the subjects were exposed (2) to estimate the average $50 \%$ illness dose. High levels of genome copies per liter of water for GI $\left(1.1 \times 10^{3}\right)$ and GII $\left(5.8 \times 10^{3}\right)$ had been detected. Intact virions, estimated by using a viability realtime quantitative PCR, represented $<4.4 \%$ to $5.6 \%$ of the total number of genomes. We estimated $50 \%$ illness doses according to the percentages of persons with gastroenteritis and the median water volumes recorded for each group (Table 2). We calculated $95 \%$ CIs by using the scenarios corresponding

\begin{tabular}{|c|c|c|c|c|c|c|c|}
\hline Person no. & Age, y & $\begin{array}{c}\text { Duration of } \\
\text { symptoms, days }\end{array}$ & $\begin{array}{c}\text { Daily water intake, } \\
\text { mL† }\end{array}$ & $\begin{array}{c}\text { Secretor } \\
\text { status }\end{array}$ & $\begin{array}{l}\text { ABO blood } \\
\text { type }\end{array}$ & $\begin{array}{c}\text { Virus } \\
\text { genogroup }\end{array}$ & Virus genotype \\
\hline 1 & 46 & 2 & $200-600$ & + & NA & l & GI.P2 Gl.2 \\
\hline 2 & 25 & 2 & $200-600$ & + & NA & II & GII.P17 Gll.17 \\
\hline 3 & 58 & 4 & $200-600$ & + & NA & II & GII.P17 Gll.17 \\
\hline 4 & 45 & 5 & $200-600$ & - & $\mathrm{O}$ & I & GI.P2 GI.2 \\
\hline $5 \ddagger$ & 29 & 3 & $200-600$ & + & $\mathrm{O}$ & NA & $\mathrm{NA}$ \\
\hline $6 \neq$ & 31 & 1 & $200-600$ & + & $\mathrm{O}$ & NA & NA \\
\hline 7 & 34 & 2 & $200-600$ & - & $\mathrm{O}$ & I & GIP2 GI.2 \\
\hline 8 & 42 & 4 & $200-600$ & + & $\mathrm{O}$ & $I+||$ & GI.P2 Gl.2 \\
\hline 9 & 45 & 5 & $601-1,000$ & - & NA & I & $\mathrm{NA}$ \\
\hline 10 & 32 & 3 & $601-1,000$ & + & A & $I+I I$ & $\begin{array}{l}\text { GI.P2_GI.2 and } \\
\text { GII.P17 Gll.17 }\end{array}$ \\
\hline 11 & 29 & 4 & $601-1,000$ & + & $B$ & $|+| \mid$ & GII.P17 Gll.17 \\
\hline 12 & 26 & 6 & $601-1,000$ & + & $\mathrm{O}$ & $I+||$ & GI.P2 GI.2 \\
\hline 13 & 41 & 9 & $601-1000$ & + & $\mathrm{O}$ & $1+11$ & $\mathrm{~N} \overline{\mathrm{A}}$ \\
\hline 14 & 25 & 4 & $>1,000$ & + & NA & $I+I I$ & Gll.P2_Gll.2 \\
\hline 15 & 55 & 2 & $>1,000$ & + & A & $I+I \mid$ & GI.P2 GI.2 \\
\hline $16 \ddagger$ & 27 & 0 & $200-600$ & - & NA & NA & $\mathrm{NA}$ \\
\hline $17 \ddagger$ & 52 & 0 & $200-600$ & - & $A B$ & NA & NA \\
\hline $18 \ddagger$ & 54 & 0 & $200-600$ & + & NA & NA & NA \\
\hline $19 \ddagger$ & 47 & 0 & $200-600$ & + & $\mathrm{O}$ & NA & NA \\
\hline $20 \ddagger$ & 59 & 0 & $200-600$ & + & $\mathrm{O}$ & NA & NA \\
\hline $21 \ddagger$ & 30 & 0 & $200-600$ & + & $\mathrm{O}$ & NA & NA \\
\hline $22 \ddagger$ & 59 & 0 & $200-600$ & - & $\mathrm{O}$ & NA & NA \\
\hline $23 \ddagger$ & NA & 0 & $200-600$ & + & $\mathrm{O}$ & NA & NA \\
\hline $24 \ddagger$ & 33 & 0 & $601-1,000$ & + & NA & NA & NA \\
\hline $25 \ddagger$ & 38 & 0 & $>1,000$ & - & NA & NA & NA \\
\hline $26 \ddagger$ & 42 & 0 & $>1,000$ & - & NA & NA & NA \\
\hline
\end{tabular}

${ }^{*} \mathrm{NA}$, not available; -, negative; +, positive. †Plastic glasses used by persons to drink water had a volume of $200 \mathrm{~mL}$. $\ddagger$ These persons did not provide a stool sample. 

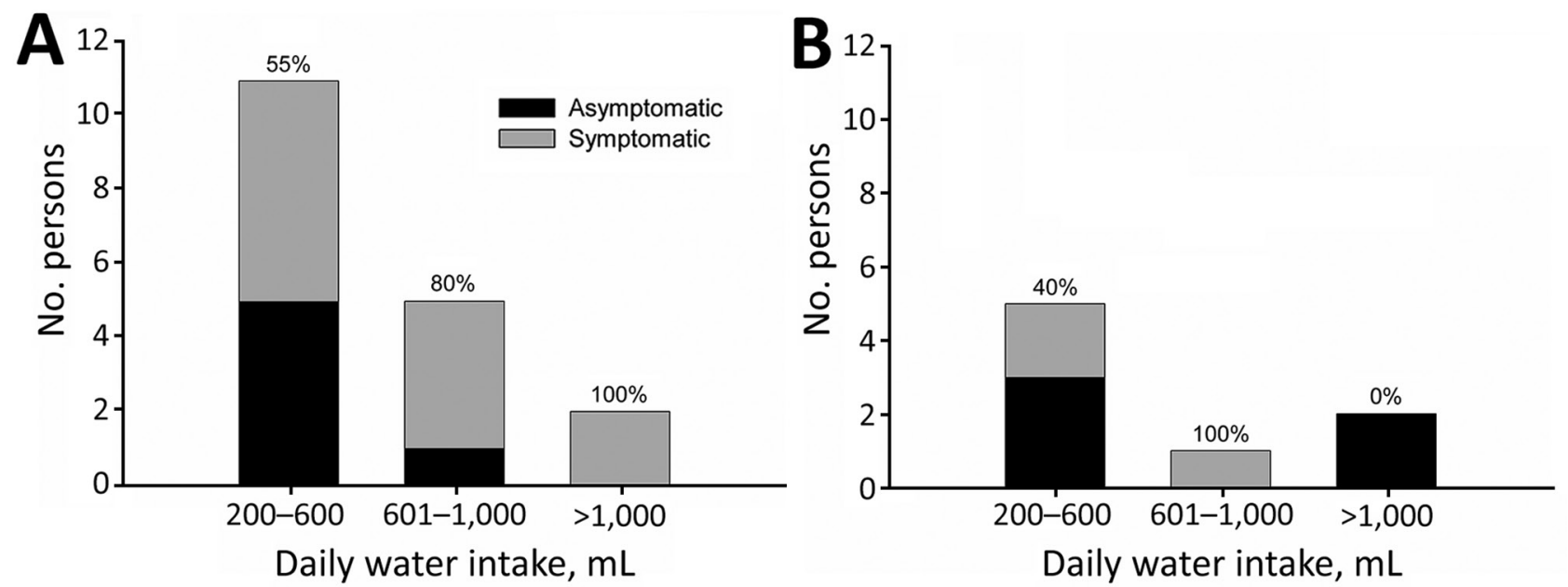

Figure. Distribution of A) secretor and B) nonsecretor persons by level of daily water intake and the occurrence of symptoms during a waterborne outbreak of norovirus, Spain. Numbers at the top of each bar indicate percentages of symptomatic persons.

to the minimum and maximum water volumes from each group. The $50 \%$ illness dose estimates for secretors were 556 (95\% CI, 319-957) genome copies/ day for GI exposures and 2,934 (95\% CI, 1,683-5,044) genome copies/day for GII exposures. For nonsecretors, the number of infected persons was too low to calculate $50 \%$ illness doses.

\section{Conclusions}

Our data showed differences in infectivity between norovirus GI and GII, which differs from what was previously observed in oyster-related outbreaks (8). Because the number of persons studied was low in both studies, factors that might modify how a particular person responds to virus exposure might partially explain these different observations. In addition, factors related to particular genotypes involved in the outbreaks might also influence infectivity. Although values estimated in this study fall within the range of $\mathrm{ID}_{50}$ and $50 \%$ illness dose data obtained by other investigators $(4,6,8)$, we observed that median values extrapolated from oyster-related outbreaks (8) are the lowest values. This trend might be caused by natural variability, different preimmune status of exposed persons, or strain differences, or the proportion of noninfectious genomes with respect to total genome copies might be lower within contaminated oysters.

Because of the interaction of norovirus with specific carbohydrates found in oyster intestinal tissues (15), these animals might specifically bioaccumulate intact infectious virions. In this regard, in our study, after we considered only those genomes incorporated in undamaged capsids, resulting 50\% illness doses for secretors were only 25 (95\% CI 15-42) for GI and 165 (95\% CI 95-284) for GII.

Because the proportion of infectious genomes might vary in each particular environmental scenario, infectivity data for norovirus relating to total and infectious genomes should be consistently investigated whenever possible for a better refinement of risk assessment approaches. Outbreaks caused by consumption of contaminated water and shellfish are often caused by multiple virus strains. Although this factor might hamper infectivity estimates, these types of studies are nevertheless valuable to risk managers and regulators for future formulation of guidelines on acceptance levels for norovirus in specific matrices.

\begin{tabular}{|c|c|c|c|c|c|c|}
\hline \multirow[b]{2}{*}{$\begin{array}{l}\text { Virus } \\
\text { genotype }\end{array}$} & \multirow[b]{2}{*}{$\begin{array}{l}\text { Ingested genome } \\
\text { copies/d }\end{array}$} & \multirow[b]{2}{*}{$\begin{array}{l}\text { Ingested infectious } \\
\text { genome copies/d }\end{array}$} & \multicolumn{2}{|c|}{ Secretors } & \multicolumn{2}{|c|}{ Nonsecretors } \\
\hline & & & $\begin{array}{c}\text { No. exposed } \\
\text { persons }\end{array}$ & $\begin{array}{c}\% \text { Symptomatic } \\
\text { persons }\end{array}$ & $\begin{array}{l}\text { No. exposed } \\
\text { persons }\end{array}$ & $\begin{array}{c}\% \text { Symptomatic } \\
\text { persons }\end{array}$ \\
\hline \multirow[t]{3}{*}{$\mathrm{GI}$} & $220-660$ & $10-29$ & 9 & 22.2 & 5 & 40.0 \\
\hline & $661-1,100$ & $30-49$ & 5 & 80.0 & 1 & 100.0 \\
\hline & $>1,100$ & $>49$ & 2 & 100.0 & 2 & 0.0 \\
\hline \multirow[t]{3}{*}{ GII } & $1,160-3,480$ & $65-196$ & 9 & 33.3 & 5 & 0.0 \\
\hline & $3,481-5,800$ & $197-327$ & 5 & 80.0 & 1 & 0.0 \\
\hline & $>5,800$ & $>327$ & 2 & 100.0 & 2 & 0.0 \\
\hline
\end{tabular}

${ }^{*} n=13$. Persons who did not provide a stool sample were excluded from the analysis. 
This study was supported in part by projects FoodFP7-311846 (European Union) and XRB-Biotechnology Reference Network (Generalitat de Catalunya).

\section{About the Author}

Dr. Guix is an associate professor in the Department of Genetics, Microbiology and Statistics, and academic secretary of the Research Institute of Nutrition and Food Safety, University of Barcelona, Barcelona, Spain. Her research interests are human foodborne enteric viruses, such as norovirus, hepatitis A, and astrovirus; molecular and clinical aspects; and the role of these viruses as food and environmental contaminants; and virus inactivation studies.

\section{References}

1. Lopman BA, Steele D, Kirkwood CD, Parashar UD. The vast and varied global burden of norovirus: prospects for prevention and control. PLoS Med. 2016;13:e1001999. https:/ / doi.org/ 10.1371/journal.pmed.1001999

2. Blanco A, Guix S, Fuster N, Fuentes C, Bartolomé R, Cornejo $\mathrm{T}$, et al. Norovirus in bottled water associated with gastroenteritis outbreak, Spain, 2016. Emerg Infect Dis. 2017;23: 1531-4. https:// doi.org/10.3201/eid2309.161489

3. Nordgren J, Svensson L. Genetic susceptibility to human norovirus infection: an update. Viruses. 2019;11:E226. https:/ / doi.org/10.3390/v11030226

4. Teunis PF, Moe CL, Liu P, Miller SE, Lindesmith L, Baric RS, et al. Norwalk virus: how infectious is it? J Med Virol. 2008;80:1468-76. PubMed https://doi.org/10.1002/jmv.21237

5. Kirby AE, Teunis PF, Moe CL. Two human challenge studies confirm high infectivity of Norwalk virus. J Infect Dis. 2015;211:166-7. https://doi.org/10.1093/infdis/jiu385

6. Atmar RL, Opekun AR, Gilger MA, Estes MK, Crawford SE, $\mathrm{Neill} \mathrm{FH}$, et al. Determination of the $50 \%$ human infectious dose for Norwalk virus. J Infect Dis. 2014;209:1016-22. PubMed https://doi.org/10.1093/infdis/jit620

7. Costantini V, Morantz EK, Browne H, Ettayebi K, Zeng XL, Atmar RL, et al. Human norovirus replication in human intestinal enteroids as model to evaluate virus inactivation.
Emerg Infect Dis. 2018;24:1453-64. https:/ / doi.org/10.3201/ eid2408.180126

8. Thebault A, Teunis PF, Le Pendu J, Le Guyader FS, Denis JB. Infectivity of GI and GII noroviruses established from oyster related outbreaks. Epidemics. 2013;5:98-110. https:// doi.org/10.1016/j.epidem.2012.12.004

9. Marionneau S, Airaud F, Bovin NV, Le Pendu J, Ruvoën-Clouet N. Influence of the combined ABO, FUT2, and FUT3 polymorphism on susceptibility to Norwalk virus attachment. J Infect Dis. 2005;192:1071-7. https://doi.org/10.1086/432546

10. Pérez-Sautu U, Sano D, Guix S, Kasimir G, Pintó RM, Bosch A. Human norovirus occurrence and diversity in the Llobregat River catchment, Spain. Environ Microbiol. 2012;14:494-502. https:// doi.org/10.1111/j.1462-2920.2011.02642.x

11. van Beek J, de Graaf M, Smits S, Schapendonk CM, Verjans GM, Vennema $\mathrm{H}$, et al. Whole-genome nextgeneration sequencing to study within-host evolution of norovirus (NoV) among immunocompromised patients with chronic NoV infection. J Infect Dis. 2017;216:1513-24. https://doi.org/10.1093/infdis/jix520

12. Kubota T, Kumagai A, Ito H, Furukawa S, Someya $Y$, Takeda N, et al. Structural basis for the recognition of Lewis antigens by genogroup I norovirus. J Virol. 2012;86:11138-50. https:// doi.org/10.1128/JVI.00278-12

13. Shanker S, Czako R, Sankaran B, Atmar RL, Estes MK, Prasad BV. Structural analysis of determinants of histo-blood group antigen binding specificity in genogroup I noroviruses. J Virol. 2014;88:6168-80. https:/ / doi.org/10.1128/JVI.00201-14

14. Shirato H, Ogawa S, Ito H, Sato T, Kameyama A, Narimatsu H, et al. Noroviruses distinguish between type 1 and type 2 histo-blood group antigens for binding. J Virol. 2008;82:10756-67. PubMed https:/ / doi.org/10.1128/ JVI.00802-08

15. Le Guyader F, Loisy F, Atmar RL, Hutson AM, Estes MK, Ruvoën-Clouet N, et al. Norwalk virus-specific binding to oyster digestive tissues. Emerg Infect Dis. 2006;12:931-6. PubMed https://doi.org/10.3201/eid1206.051519

Address for correspondence: Albert Bosch, Department of Genetics, Microbiology and Statistics, School of Biology, University of Barcelona, Diagonal 643, 08028, Barcelona, Spain; email: abosch@ub.edu 